Proc. Indian Acad. Sci. (Earth Planet. Sci.), Vol. 90, No, 3, November 1981, pp. 273-?80

(C) Printed in Indix.

\title{
Magnetic properties of mafics and ultramafics from Eastern Ghats
}

\author{
V BHASKARA RAO and A LAKSHMIPATI RAJU \\ Department of Geophysics, Andhra University, Waltair 530 003, India
}

MS received 20 December 1980; revised 20 August 1981

\begin{abstract}
Magnetic properties, namely intensity of natural remanent magnetisation (NRM) and magnetic susceptibility, of mafic and ultramafic formations of Eastern Ghats belt in the Godavari Districts, Andhra Pradesh are studied. The formations sampled for the study are, iron-ore, chromite-ore, amphibolite, gabbro, charnockite and khondalite gneiss. Mincralogical differences in iron-ore and the degree of martitisation are reflected in magnetic susceptibility. NRM and susceptibility of chromite-ore are feeble. The gabbro exhibits strong magnetic properties becance of its contiguity with iron formation. The Koenigsberger ratio is found to indicate relative palaeomagnetic stabilsty.
\end{abstract}

Keywords. Natural remanent magnetisation susceptibility; Koenigsberger ratio; volume percent magnetite; palaeomagnetic stability; mafics and ultramafics.

\section{Introduction}

Different ultramafic bodies and their associated rocks occur in the southern Indian peninsula along major planes of weakness in the crust. In the Eastern Ghats belt they are represented by, among others, magnetite bearing gabbro and chromite bearing pyroxenites. They are associated with charnockites.

The evolutionary history of the charnockite-khondalite system is marked by succeeding geosynclinal facies of sediments and volcanic effusives with associated syntectonic mafic and ultramafic intrusives. The last phase of the Eastern Ghats orogeny culminated in a series of basement controlled NE-SW shear zones along the margins of the charnockite-khondalite belt. The tectonic evolution of the Precambrian provinces in South India has brought out many manifestations of the upper mantle during the Archaean-Proterozoic orogenies. The ultramafics localised along NE-SW shear zones in the margins of the charnockite belts, probably represent late tectonic intrusives during the Eastern Ghats orogeny (Narayanaswamy 1970). They might have been emplaced into the Eastern Ghat suite of rocks prior to the upliftment (Karunakaran 1970). 
The samples are collected from four localities namely Addatigala, Devipatnam, Tekuru and Eleswaram (Figure 1a) for laboratory measurements in conjunction with magnetic prospecting for iron-ore (Lakshmipati Raju 1977)

\section{Geological setting}

According to Ray (1967), the Eastern Ghats region is a portion of the oldest Precambrian crust in India. Khondalites, which are characteristically of granulite facies have charnockites as their almost constant companion. Granitic gneisses and anorthosites prevail in many parts. Ultramafic and related rocks occur as magnetite-ore bearing gabbro-norite types and chromite bearing pyroxenites.

The country rocks in the area, in general, are khondalite gneisses and schists, charnockite rocks, pink granites and pegmatites. In the localities of Addatigali, Devipatnam and Tekuru, the ultramafic rocks comprise variants of pyroxene, hornblende and plagioclase including pyroxenite, gabbro and amphibolite. At Addatigala the iron-ore bands are within the gabbroic zone trending NE-SW with a dip of $60^{\circ} \mathrm{SE}$ and conformable with the country rock gneisses. At Devipatnam the ore occurs as reefs and veins exhibiting both concordance and discordance with the country rock formations and with nearly vertical dips. At Tekuru also the mafic-ultramafic issemblages are associated with iron-ore. Chromite is enclosed within pyroxenites, showing a gradational sequence, as bands in conformable relationship with the khondalite gneisses. It strikes at $\mathrm{N} 60^{\circ} \mathrm{E}$ with a dip of $75^{\circ} \mathrm{SE}$.

\section{Sample collection and laboratory measurements}

The various formations sampled from different localities are listed in table 1 . Locations of sampling sites are shown in figure $1 \mathrm{~b}$. In the laboratory, cores of $2.5 \mathrm{~cm}$ diameter, are drilled from the samples with a diamond drill and specimens $(2.5 \mathrm{~cm}$ long) are cut.

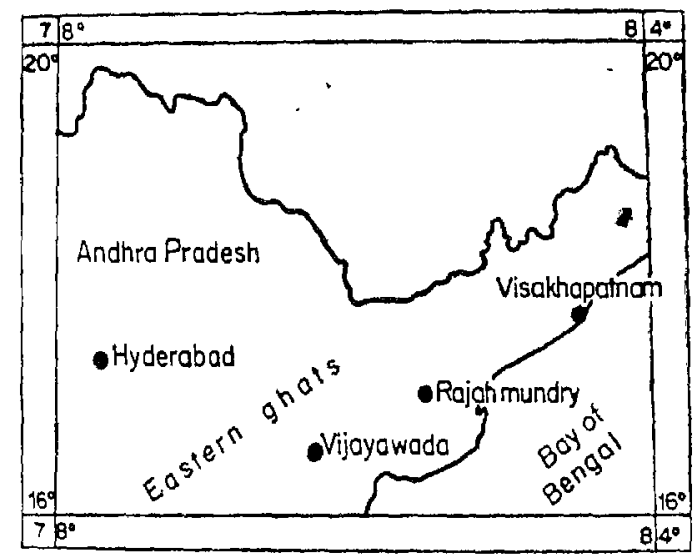

Figure 1a. Index map. 
Table 1. Details of formations sampled.

\begin{tabular}{ll}
\hline Locality & Formation sampled \\
\hline Addatigala & $\begin{array}{l}\text { Iron-ore } \\
\text { Gabbro } \\
\text { Charnockite }\end{array}$ \\
Devipatnam & Iron-ore \\
& Amphibolite \\
& Biotite granite gneiss \\
& Charnockite \\
& Iron-ore \\
Chromite-ore \\
Kekury & Khondalite gness \\
& Charnockite \\
\hline
\end{tabular}

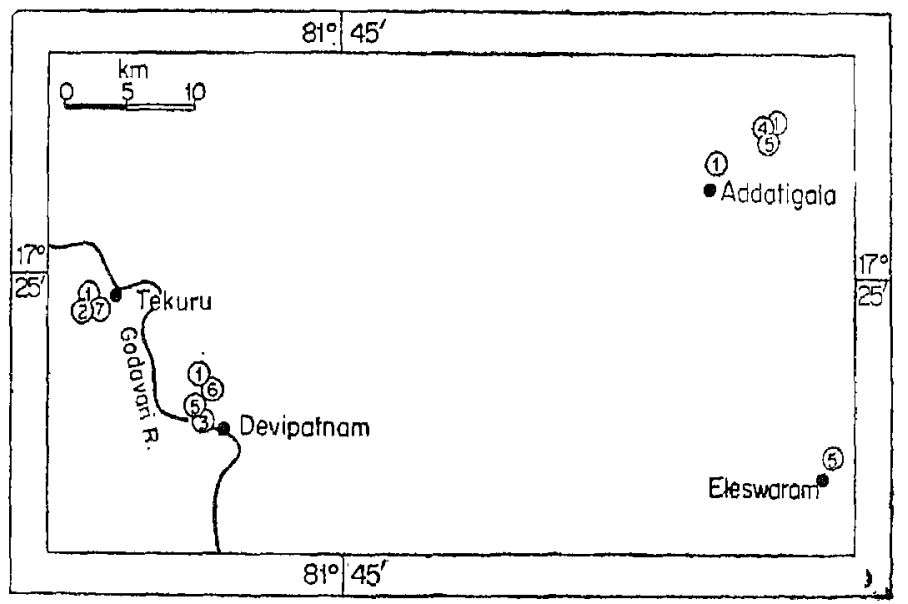

Figure 1b. Locations of sampling sites : [1] Iron-ore, [2] Chromite-ore, [3] Amphibolite, [4] Gabbro, [5] Charnockite, [6] Biotite granite gneiss, [7] Khondaiite gneiss.

Intensity and direction of NRM are measured with an astatic magnetometer having a sensitivity of $1 \times 10^{-6} \mathrm{oe} / \mathrm{mm}$. Magnetic susceptibility is measured with a susceptibility meter (Likhite and Radhakrishna Murthy 1965) in which the Heimholtz coil assembly produces an alternating magnetic field of variable strength, up to a maximum of $10 \mathrm{oe}$, at a constant frequency of $576 \mathrm{~Hz}$. The measurements are made at a field strength of $0.5 \mathrm{oe}$. Specific gravity of all the specimens is determined and polished sections of the ore samples are examined under an ore microscope to identify the opaque minerals. Some representative ore samples are analysed chemically. 
4. Results of measurements

All the measured values of NRM intensity $(J)$ and magnetic susceptibility $(k)$ are presented in the form of frequency histograms for both normal and $\log$ normal distributions in figure 2 . The ranges in $J$ and $k$ are listed in table 2. Among all the types listed only iron-ore exhibits a wide range of values for $J$ and $k$. The higher values of $J\left(1021-2658 \times 10^{-3}\right.$ e.m.u. $)$ are shown by four specimens of enriched ore from Devipatnam. In general, the

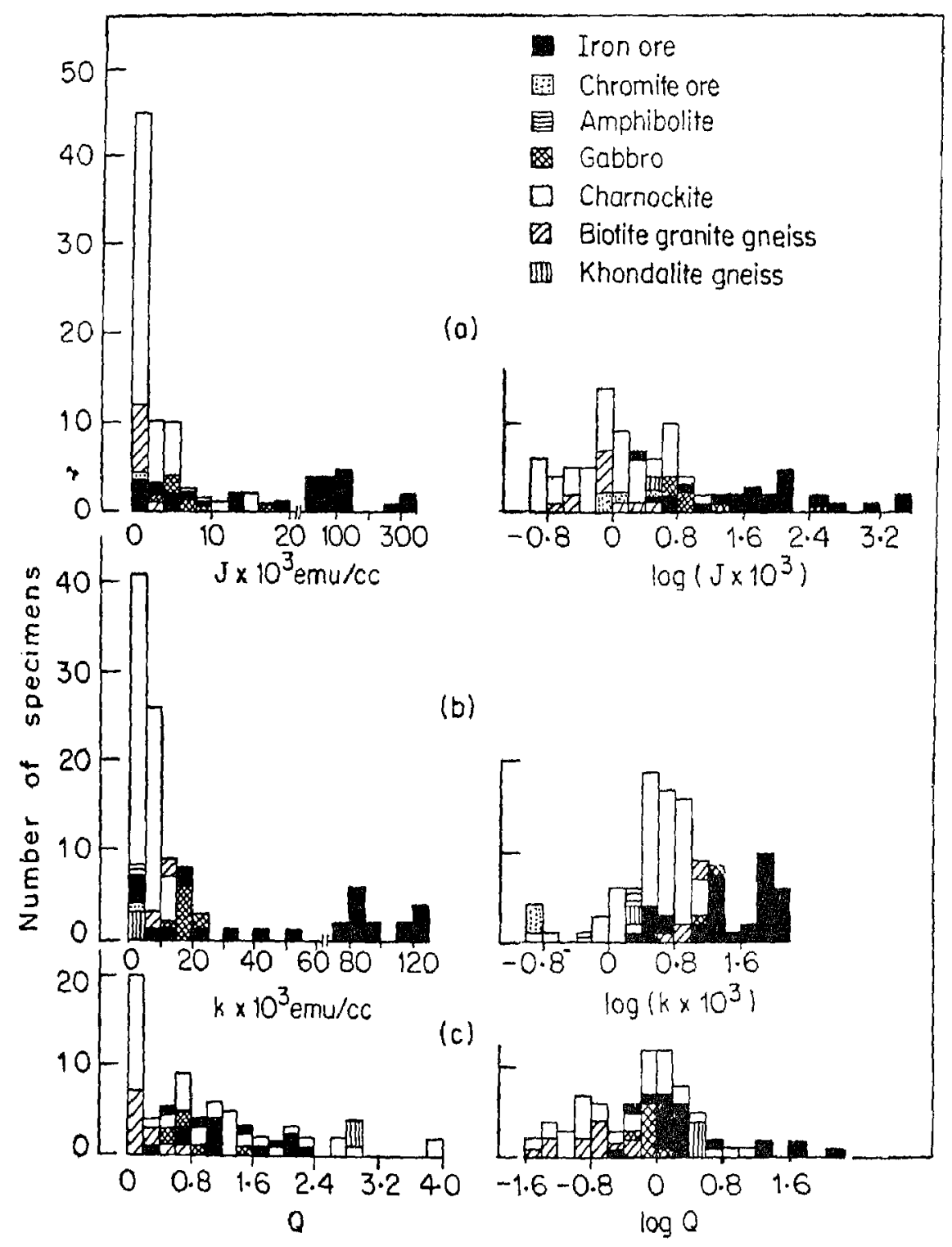

Figure 2. Histograms of : (a] intensity of natural remanent magnetisation, [b] Susceptibility and [c] Koenigsberger ratio. 


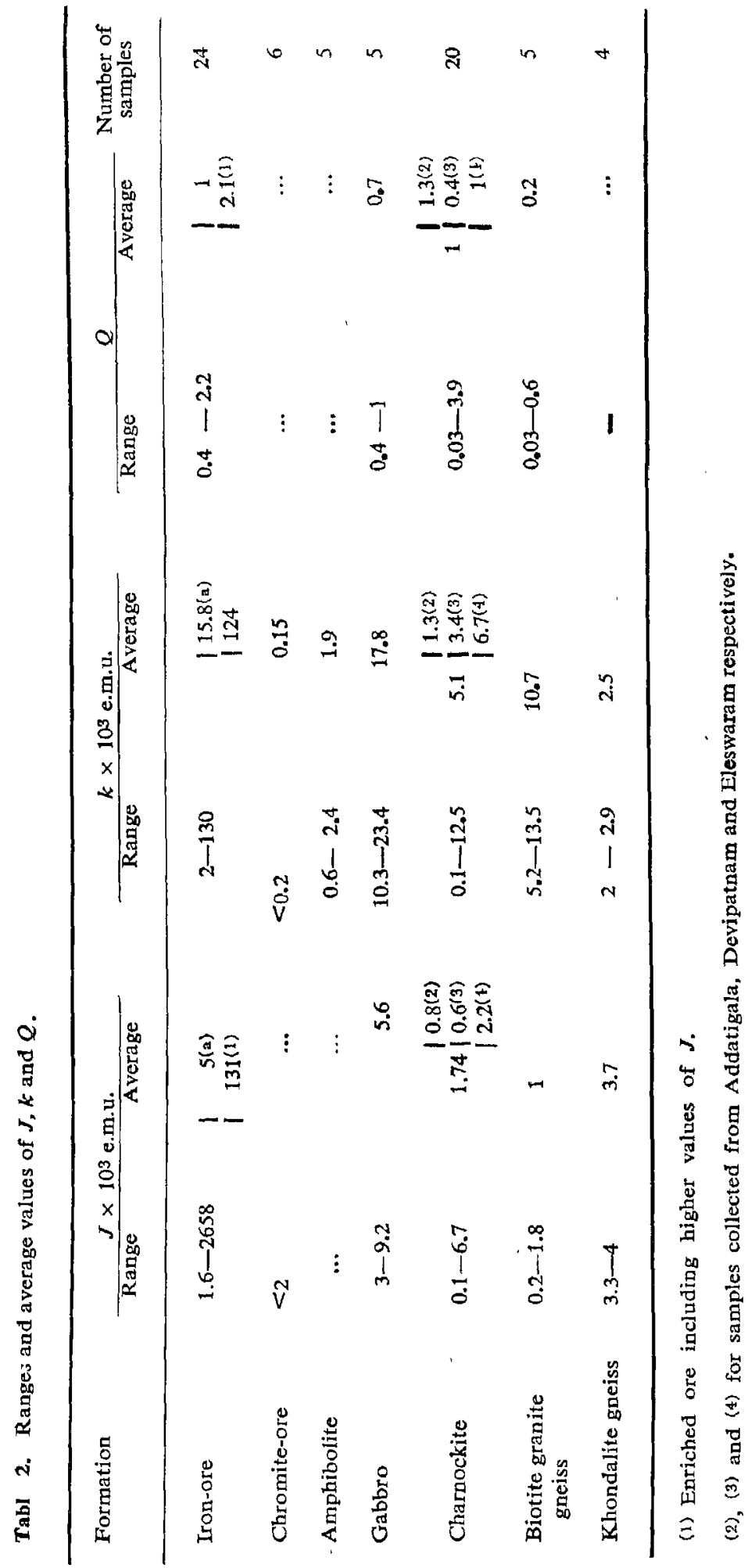


entiched ore specimens, from Addatigala, Devipatnam and Tekuru, have intensities in the range $25 \times 10^{-3}-138 \times 10^{-3}$ e.m.u. with an average of $131 \times 10^{-3}$ e.m.u. Low values in the range $1.6 \times 10^{-3}-8.7 \times 10^{-3}$ e.m.t. with an avarage of $5 \times 10^{-3}$ e.m.u. are exhibited by samples collected from the contact zone with the gabbroic rocks. The susceptibilities of enriched ore are in the range, $80 \times 10^{-3}$ $130 \times 10^{-3}$ e.m.u. Chromites thave low values of $J$ as well as $k$. The values for gabbro and khondalite gneiss are on the high side. The Koenigsberger ratios $(Q)$ are calculated from measured values of $J$ and $k . \quad Q$ is expressed as $Q=J / k H$ where $H$ is strength of the earth's field. The values of $Q$ also are presented as frequency histograms in figure 2 and the ranges are indicated in table 2.

\section{Discussion of results}

In view of the wide range of values it appears from figure 2 that $\log$ normal distribution is better suited. The average values of $J, k$ and $Q$ are listed in table 2 . Averages for $J$ and $k$ corresponding to iron-ore (a) and gabbro are of the same order. This may be explained by the fact that the ore occurs in gabbro and that the sampling locations are juxtaposed. The NRM intensity and susceptibility of chromites are feeble. From the table it is evident that charnockites from Eleswaram have higher average values of $J$ and $k$ than those from other localities, which are associated with iron-ore.

Susceptibilities are plotted against specific gravities in figure 3. The points for iron-ore form into four distinct groups named as $A, B, C$ and $D$. Groups

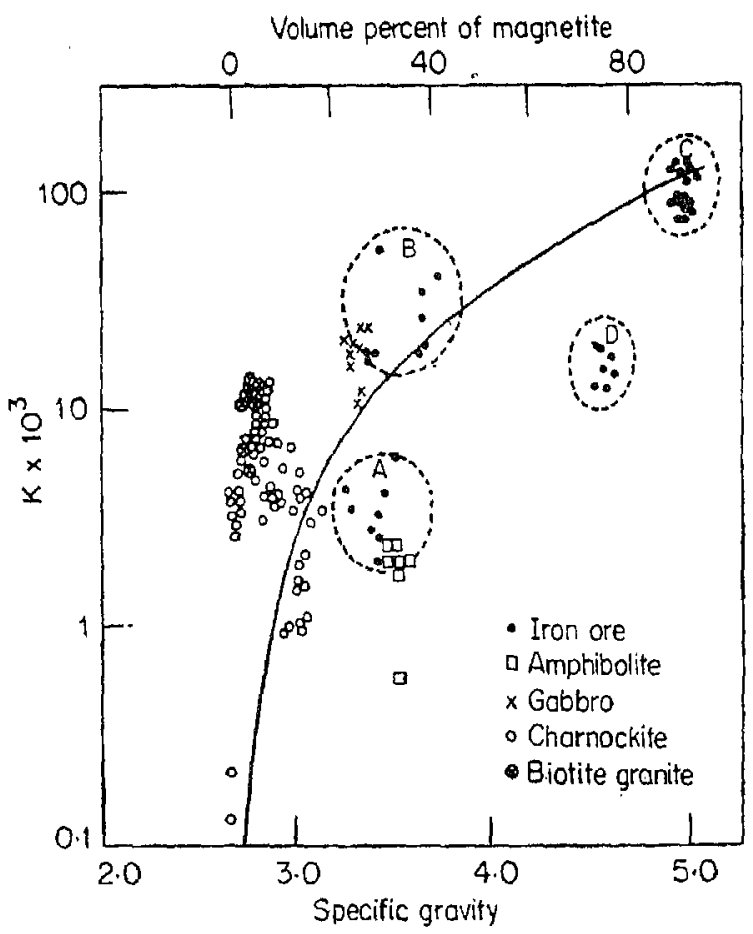

Figure 3. A plot of susceptibilities against specific gravities. 
$A, B$ and $D$ correspond to the ore from Addatigala, samples of group $D$ being from the site closer to the village (figure $1 \mathrm{~b}$ ). Group $C$ corresponds to the enriched ore from Addatigala, Devipatnam and Tekuru. Groups $A$ and $B$, with average specific gravities of 3.4 and 3.6 respectively, represent samples from a single site and the former group has lower susceptibility values than the Iatter. Group $C$ with average specific gravity approaching that of pure magnetite has higher ${ }^{3}$ values of $k$. These differences in susceptibility are probably reflecting the mineralogical differences observed in polished sections and chemical analysis.

In group $B$ magnetite occurs as irregular bands in the host rock. Exsolved lamellae of ilmenite and spinel are seen in magnetite. Most of the magnetite rains are unaltered and few have been subjected to martitisation. Patches of unreplaced magnetite are seen in a network of haematite. Magnetite repre-

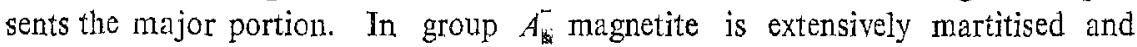
patches of relict mugnetite are rarely seen. Haematite is the predominant constituent. Samples of group $D$ contain roughly $70 \%$ of haematite and $30 \%$ of magnetite. The mineralogical character of enriched ore collected from the three different localities is not as varied. The ores from Addatigala contain unaltered magnetite as the only constituent. More than $95 \%$ of the ore from Devipatnam contains magnetite. Slender scales of exsolved ilmenite are observed. Though few of the magnetite grains are in the initial stages of martitisation, alteration is negligible. The ore samples collected from Tekuru contain mostly magnetite with subordinate amounts of intergrown euhedral grains of ilmenite. Regularly oriented thin blades of exsolved ilmenite are seen in magnetite. Magnetite is rather unaltered, though few grains are seen to be replaced by fine scales of haematite, amounting to more than $95 \%$.

The extensive martitisation in group $A$ may be responsible for low susceptibilities while low magnetite content explains group $D$. Close points in group $C$ which represent the enriched ore from Addatigala, Devipatnam and Tekuru, probably reflect the mineralogical similarity of the ores as is clear from the above discussion.

Many expressions, for the relationship between susceptibility and magnetite content, deduced by Slichter (1929), Grenet (1930), Nagata (1940), Kato (1941), Werner (1945), Mooney and Bleifuss (1953), Rao (1956), Balsley and Buddington (1958) Sauck (1972), Bath (1962), Jahren (1963), Hood (1964) and others are available. Werner's expression (Hansen, 1966) for magnetite ores is used in computing the line in figure 3 and for this a value of 1.7 is substituted for the susceptibility of magnetite. The line appears to be a reasonable fit to the data.

It was pointed out by Radhakrishna Murty and Mishra (1966) that high values of $Q$ are generally associated with high stability of magnetisation in rocks. Magnetisations with $Q$ values of one or more are usually considered as stable. Biotite granite gneisses and charnockites from Devipatnam (table 2) have low $Q$ values. As anticipated from these low values the behaviour of charnockites during a. c. demagnetisation was not satisfactory and biotite granite gneisses did not give stable directions (Lakshmipati Raju 1977). On the other hand ironore, gabbro and other charnockites, with $Q$ values around one, gave stable directions. 
Acknowledgement

The authors are thankful to the National Geophysical Research Institute, Hyderabad, for providing facilities for the magnetic measurements reported.

\section{References}

Balsley J R and Buddington A F 1958 Econ. Geol. 53777

Bath G D 1962 Geophysics 27627

Grenet G 1930 Adn. Phys. Tenth Series 13263

Hansen D A 1966 Mining Geophysics 1359

Hood Peter 1964 Geopllys. Prosp. 12440

Jahren C E 1963 Geophysics 28756

Karunakaran C 1970 Proc. II Symp. UMP NGRI Hyderabad 361

Kato Y 1941 Sci Rep. Tohufiu Imp. Univ. Sendai Japan I Sr. 29602

Lakshmipati Raju A 1977 Magnetic studies on some iron-ore deposits of Godavari districts, Andhra Pradesh, India Ph.D Thesis, Andhra University, Waltair

Likhite S D and Radhakrishna Murty C 1965 Bull Natl. Geophys. Res. Inst. India 31

Mooney $\mathrm{H}$ M and Bleifuss R 1953 Geophysics 18383

Nagata T 1940 Bull Earthquake Res. Inst. 18102

Narayanaswamy S 1970 Proc. II Symp. UMP Hyderabad, India 377

Radhakrishna Murty C and Mishra D C 1966 Bull. Natl. Geophys. Res. Inst. India 4103

Rao V B 1956 Geopltysics 211100

Ray S 1967 Proc. Symp. UMP Hyderabad, India 249

Sauck W A 1972 Econ. Geol. 67383

Slichter L B 1929 Trans. AIME 81238

Werner S 1945 Sveriges. Geol. Unders. Arsb. 391 